\title{
HYSTOLOGICAL ANALYSIS OF OVARIAN DEVELOPMENT OF THE CHARACIFORM Oligosarcus hepsetus (CUVIER, 1829) IN A BRAZILIAN RESERVOIR
}

\author{
SANTOS, R. N., ANDRADE, C. C., SANTOS, A. F. G. N., SANTOS, L. N. and ARAÚJO, F. G. \\ Laboratório de Ecologia de Peixes, Universidade Federal Rural do Rio de Janeiro, km 47, Antiga Rodovia Rio-SP, \\ CEP 23851-970, Seropédica, RJ, Brazil \\ Correspondence to: Francisco Gerson Araújo, Laboratório de Ecologia de Peixes, \\ Universidade Federal Rural do Rio de Janeiro, km 47, Antiga Rodovia Rio-SP, CEP 23851-970, \\ Seropédica, RJ, Brazil, e-mail: gerson@ufrrj.br \\ Received January 13, 2003 - Accepted October 27, 2003 - Distributed February 28, 2005
}

(With 3 figures)

\begin{abstract}
A histological analysis was performed of the ovarian development of Oligosarcus hepsetus (Cuvier, 1829), a medium-sized carnivorous Characiform species in the Lajes reservoir, Brazil. A total of 125 fishes, collected monthly between April 2001 and June 2002 were examined by routine macroscopic and histological techniques. Eight phases of the oocyte development were described, and 4 stages and 4 substages of gonadal development were proposed. Spawning in reservoirs, similarly to that in rivers, is in batches, which favors juvenile survival and suggests that the impoundment of this area did not influence the reproductive strategy of this very successful species in a dammed environment.
\end{abstract}

Key words: reproductive strategy, spawns, Characiforms, reservoirs, Brazil.

\section{RESUMO}

\section{Análise histológica do desenvolvimento ovariano do Characiforme Oligosarcus hepsetus (Cuvier, 1829) em um reservatório oligotrófico brasileiro}

O desenvolvimento ovariano do peixe-cachorro Oligosarcus hepsetus (Cuvier, 1829), um characiforme carnívoro de pequeno a médio porte, foi analisado macro e microscopicamente. Um total de 125 espécimes, coletados mensalmente entre abril de 2001 e junho de 2002, foram examinados. Oito fases de desenvolvimento ovocitário foram descritas e quatro estágios e quatro substágios de desenvolvimento gonadal foram propostos. $O$. hepsetus apresenta desova do tipo parcelada no reservatório de Lajes, sugerindo que a estratégia reprodutiva da espécie não foi influenciada por eventuais mudanças físicas e químicas no ecossistema aquático causadas pelo represamento. O elevado grau de sucesso dessa espécie na represa e sua elevada abundância reforçam essa hipótese.

Palavras-chave: estratégia reprodutiva, desova, Characiformes, reservatório, Brazil.

\section{INTRODUCTION}

Oligosarcus hepsetus (Cuvier, 1829) is a smallto medium-sized carnivorous fish widely spread in almost all freshwater environments in southeastern Brazil. Despite its low commercial value, $O$. hepsetus is a very common Characidae species in many rivers and lakes in this area, inhabiting mainly densely vegetated shallow microhabitats that are abundant in small tributaries or in littoral zones of the main rivers. At Lajes reservoir, the largest impoundment of Rio de Janeiro State, this species ranks among the most abundant in experimental fisheries, which suggest its successful adaptation to artificial lentic conditions (Araújo \& Santos, 2001). The reservoir was built between 1905 and 1908 to dam streams and divert small rivers to generate hydroelectricity (Araújo \& Santos, 2001). Many kinds of aquatic organisms 
inhabit the reservoir, including 28 fish species, of which 22 are native and 6 are introduced. These species must have developed some strategy to adapt to, and coexist in, this almost 100-year-old environment.

Several factors may affect the fish lifecycle, but reproduction plays an important role in the adaptive success of a species, since it indicates the potential of a population to produce viable descendents (Vazzoler, 1996). Studies on fish reproduction may be used to support fish management and conservation programs designed to maintain or improve fish stocks (Marques et al., 2000). For projects of this kind, an accurate portrayal of gonad morphology is fundamental in identifying and describing the stages of gonadal development, which are the basis for assessing the spawning period, fecundity, length at the first maturation, and other important data related to the reproductive strategy (Vazzoler, 1996). Present histological techniques have significantly increased precision and accuracy of the results obtained in such studies (Rizzo \& Bazzoli, 1993; Palmer et al., 1995; Sarre et al., 1997).

Although some aspects of the biology of Oligosarcus hepsetus and its congeners in rivers are already known, few studies have dealt with the gonadal development of these species in artificial lentic environments, where reproduction of most Characidae seems less successful than it is in streams and rivers (Bazzoli \& Godinho, 1991; Agostinho et al., 1997). Likewise, few studies have used histological techniques to describe at high-accuracy levels the gonadal stages of Oligosarcus species.

The aim of this study was to describe oocyte development and determine gonadal development stages of $O$. hepsetus in Lajes reservoir; the gonodosomatic index was also used to indicate and/or validate those stages of development. We use only females because: a) they are better indicators of the spawning season than males, which are usually ripe for long periods; $b$ ) the amount of new descendents is strongly dependent on the number and quality of oocytes, since the production of spermatozoids is usually high; and c) the oocytes determine the synthesis and maintenance of embryo storages (Chaves, 1991).

\section{MATERIAL AND METHODS}

\section{Study area and sample collection}

Lajes reservoir $\left(22^{\circ} 42^{\prime}-22^{\circ} 50^{\prime} \mathrm{S}\right.$; 43ํำ $44^{\circ} 05^{\prime} \mathrm{W}$ ), a major impoundment in Rio de Janeiro
State, is located on the upper slopes of the Serra do Mar on the southeastern Brazilian coast. The reservoir, located at ca. $415 \mathrm{~m}$ above mean sea level, presents a ca. $30 \mathrm{~km}^{2}$ area and is a well preserved oligotrophic lake, surrounded by stretches of Atlantic Forest without large urban-industrial centers (FEEMA, 1988; Barroso, 1989).

Fishes were collected between January 1999 and April 2002 using gill nets $(20 \times 2 \mathrm{~m}$ with 2.5 $5.5 \mathrm{~mm}$ mesh size). The nets were set up by day's end and collected next morning, after almost $12 \mathrm{~h}$. All fishes were kept in isotherm recipients in the field and preserved on ice at $4^{\circ} \mathrm{C}$, subsequently being transferred to the laboratory for gonad dissection and measurements.

\section{Laboratory procedure and data analysis}

A total of 125 females ranging from 120 to $244 \mathrm{~mm}$ in total length (TL) and weighing 53.3 to $293 \mathrm{~g}$ (total weight) were caught. The preserved ovaries were embedded in paraffin, sectioned at a 5-7 $\mu \mathrm{m}$ thickness, and stained with Harris hematoxylin and eosin (H\&E). At least two slides were prepared for each ovary.

The description of each oocyte development phase was made according to terminology proposed by Palmer et al. (1995). The gonadosomatic index (GSI) was obtained according to the equation: GSI = GW/(TW-GW) $\times 100$, where: GW = gonad weight, and $\mathrm{TW}=$ total body weight. Comparisons of GSI means were performed along the development stages using one-way analysis of variance (ANOVA).

\section{RESULTS}

\section{Morphology of the ovaries}

Ovaries are cylindrical paired organs fused at a posterior edge that extends up to the oviduct. They are also dorsally situated in the coelomic cavity and ventrally in relation to the kidneys and gas bladder. According to maturity stages, they change in size, color, and turgidity. Macroscopic analysis showed that the resting ovaries presented small sizes and a gelatinous-semitransparent appearance, while advanced maturing and mature ovaries had a globularyellowish one. Histological sections revealed that ovaries presented no veins and medullar zones as is the case for most teleosteans. The inner wall presented a conjunctive tissue capsule, also called the ovarian tunic, formed by straight muscle fibers and blood vessels. The ovarian tunic projects inside the ovaries, 
along the ovarian lumen, forming the ovuliferous lamellas, in which were found oocytes in different development phases according to ovary maturity stage.

\section{Oocyte development}

Oogenesis begins with an oocyte growth resulting from the developing characters of the germinative cells (Gomes et al., 2001). Overall, eight oocyte development phases were identified for the females of $O$. hepsetus, and described as follows:

First growth phase: oogonia (Fig. 1A). These were the smallest oval cells $(7.5-10 \mu \mathrm{m})$ of germinative lineages, and presented a large central nucleus and slightly stained cytoplasm. The oogonias appeared singly or in small nests.

Second growth phase: chromatin nucleolus oocytes (Fig. 1A). These originated from oogonia and were situated close to them. They had little cytoplasm, a large and light staining nucleus and central nucleoli. The oocytes $(20-30 \mu \mathrm{m})$ were found wrapped in pre-follicular cells.

Third growth phase: early perinucleolus oocytes (Fig. 1A). They were larger $(38-48 \mu \mathrm{m})$ in relation to earlier oocytes, had basophilic cytoplasm, a large and voluminous nucleus, and several small rounded nucleoli adhering to a small membrane called the cariotheca. They were wrapped in a single layer of pavement follicular cells.

Fourth growth phase: late perinucleolus oocytes (Fig. 2C). The oocytes measured 69-85 $\mu \mathrm{m}$ and showed low affinity with hematoxylin. The nuclei were voluminous and, presented multiple peripheral nucleoli with an oval or spherical appearance. A layer formed from a couple of pavement follicular cells, or a single one, bordered the oocytes.

Fifth growth phase: yolk vesicle (Fig. 1B). The 195-210 $\mu \mathrm{m}$ oocytes had a spherical appearance but their nucleus had become irregular in shape, with the nucleoli located at the peripheral zones. During this oocyte developmental stage, a cortical vessel appeared in the cytoplasm as unstained "empty" vacuoles. These vesicles were first situated at the cytoplasm periphery, and subsequently moved to the inner cell zones. The zona radiata, also called corion, was observed between the oocyte and follicular cells. This structure resembled a thin layer, stained slightly purple by eosin during the early oocyte development stages as opposed to the thick and ruffled shape observed in advanced oocyte phases.

Sixth growth phase: vitellogenesis (Fig. 1C). The oocytes measured between 570-750 $\mu \mathrm{m}$ and showed extra-vesicular yolk deposition that first appeared as minuscule granules at the inner side of zona radiata, but became significantly larger, ultimately occupying all of the cytoplasm. The nucleus had an irregular outline and contained various peripherical nucleoli. The zona radiata became more conspicuous $(9.2 \mu \mathrm{m})$ and the follicle cells presented a double layer, the outer one formed by pavimentous cells and the inner, by cuboidal-shape cells.

Seventh growth phase: vitellogenic (mature) oocytes (Figs. 1E and 2C). They were the largest ovarian cells $(850-1020 \mu \mathrm{m})$, with protein yolk granules (protein vitellus) and cortical vesicles (lipid vitellus). The yolk vesicles were size-increased and located on the cytoplasm periphery; yolk granules were larger. The cytoplasm was more voluminous and had a grainy appearance. The radial striae occurred in the zona radiata that measured about $12.3 \mu \mathrm{m}$. The follicle cells became prismatic, were arranged in columns, and the theca presented a high vascularization degree.

Eighth growth phase: post-ovulatory follicles (Figs. 1D and 2F). After maturity, follicles broke down to allow oocyte release; post-ovulatory follicle formation followed.

Atresic follicles (Figs. 1F and 2F): These showed an irregular shape, intense cell disorder with wrinkled follicles; breakdown of the zona radiata, disordered yolk liquefaction and cytoplasm, and follicular cell invasions (process of phagocytosis). This degeneration pattern was observed in all phases of oocyte development, but it was more common in late maturity oocytes due to the higher susceptibility caused by zona radiata breakdown.

\section{Ovarian development stages}

Four stages and 4 sub-stages of ovarian development were determined based on macro- and microscopic comparisons and considering the maturation scale proposed for teleosteans by Vazzoler (1996).

1. Resting (Fig. 2A): Ovaries presenting small sizes, with a filliform and translucent appearance. Oocytes not visible to the naked eye. Oocytes mainly in their initial development phases, with early perinucleolus and late perinucleolus phases predominating. Resting ovaries were typical of sexually mature but not yet spawning fishes, or post-spawn fishes recuperating before the beginning of a new reproductive cycle. 

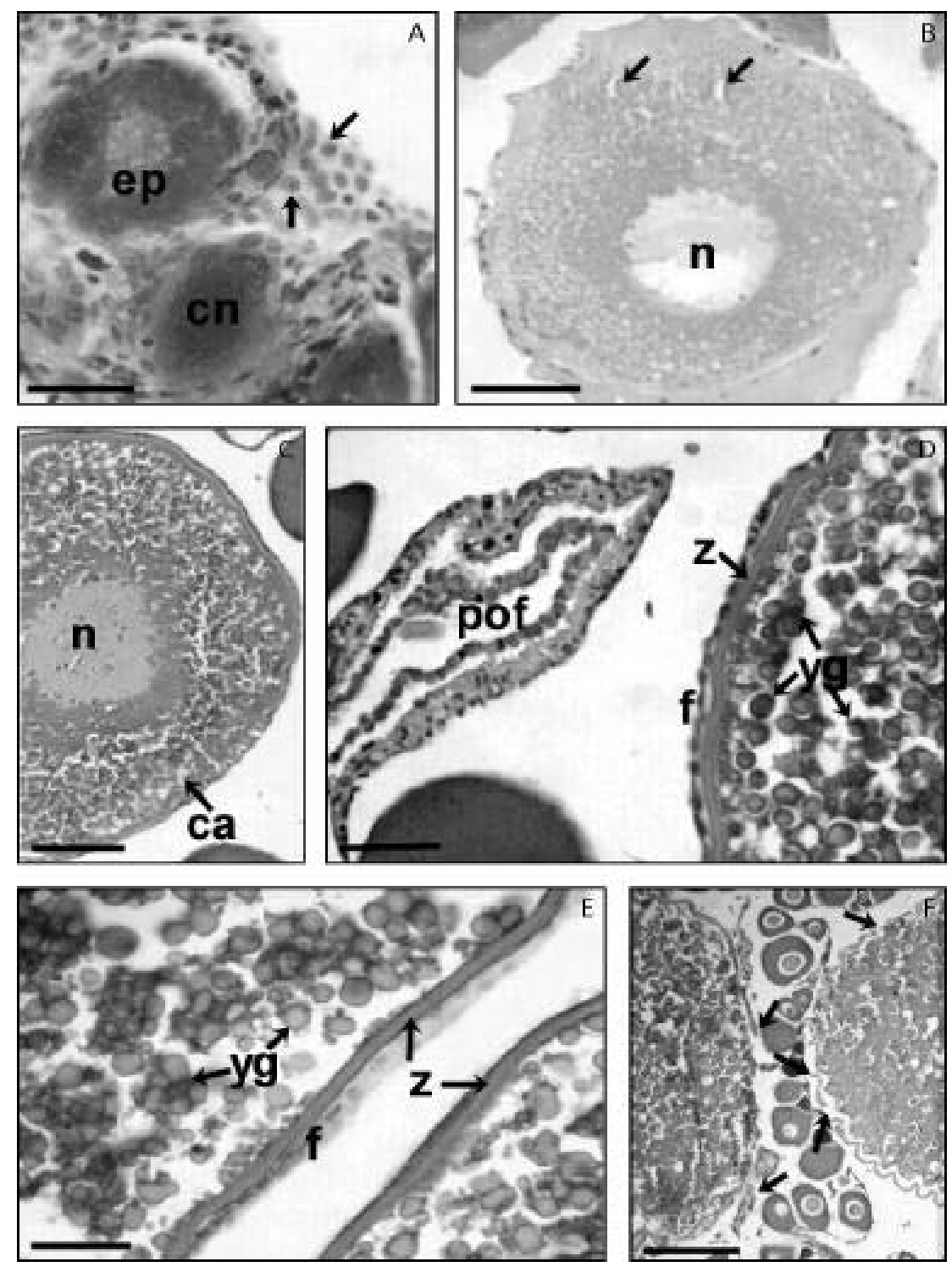

Fig. 1 - Histological sections of ovaries of $O$. hepsetus showing oocyte development and post-ovulatory follicles. (A) Oogonia (arrows), chromatin nucleolus stage (cn), early perinucleolus stage (ep), scale bar $=30 \mu \mathrm{m}$. (B) Yolk vesicle stage oocyte, showing yolk vesicles (arrows), nucleus (n), scale bar $=30 \mu \mathrm{m}$. (C) Vitellogenic oocyte, cortical alveoli (ca), nucleus (n), scale bar $=250 \mu \mathrm{m}$. (D) Post-ovulatory follicle (pof), follicle cells (f), zona radiata (z), yolk globules (yg), scale bar $=30 \mu \mathrm{m}$. (E) Mature oocytes, follicle cells (f), zona radiata (z), yolk globules (yg), scale bar $=30 \mu \mathrm{m}$. (F) Follicles showing signs of atresia with zona radiata beginning to deteriorate (arrows), scale bar $=250 \mu \mathrm{m}$.

2. Maturing (Figs. 2B and 2C): An increase in ovarian volume observed, as well as intense vascularization. Oocytes, still small-sized, may be visible to the naked eye. Color varying from white-yellow, in early maturing, to orange-yellow in the late stages. Since there are gradating changes in oocyte size and colorations, this stage was divided into two sub-stages: initial maturing (2a) and advanced maturing (2b). In sub-stage $2 a$, oocytes in phases I to $\mathrm{V}$ are shown, with higher frequency in phase V. In sub-stage $2 \mathrm{~b}$, ovaries presented a larger size compared to the previous sub-stage, showing oocytes in phases I to VII, and higher frequency of oocytes in phase VI.

3. Mature (Fig. 2D): Ovaries show the largest volume, occupying the whole coelomic cavity. Intense vascularization and orange color is displayed. Histological sections showed high oocyte frequencies in phase VII, and some oocytes in reabsorption. 
4. Spawned (Figs. 1D and 2E): This stage was divided into two sub-stages: 4a (partially spawned) and $4 \mathrm{~b}$ (totally spawned). In substage $4 \mathrm{a}$, ovaries presented hemorrhagic areas and showed flaccidity and reduced volume. A large number of oocytes can be seen by the naked eye. There are oocytes in phases I to VII, oocytes in reabsorption, and empty follicles. In sub-stage $4 \mathrm{~b}$, ovary volume is reduced, flaccid, and hemorrhagic. No oocyte remains could be seen by the naked eye. Many empty follicles and oocytes undergoing reabsorption are shown.

\section{Gonadosomatic Index (GSI)}

Significant differences were detected between the highest mean values for GSI in the mature stage, and the lowest values recorded for resting and spawned stages, according to ANOVA ( $\mathrm{F}=36,9$; $\mathrm{p}<0.01$ ) (Fig. 3). In the advanced maturing substage the GSI values were higher than for the resting and spawned stages, but lower than those for the mature stage $(\mathrm{p}<0.01)$. This pattern was also observed in the partially spawned sub-stage, but with less weighty evidence $(\mathrm{p}<0.05)$.

\section{DISCUSSION}

Oligosarcus hepsetus ovaries are classified as cystovarian (Hoar, 1969), as they present central and continuum lumen with the oviduct extending toward the urogenital aperture. This pattern differs from that of some teleosteans (e.g., Salmoniformes) whose gonads open to the coelomic cavity, with the oocytes being expelled by funnels (Narahara, 1991), which characterizes the semi-cystovarian type.

Eight phases of oocyte development were described for $O$. hepsetus in the Lajes reservoir. The number of phases can change according to species and the criteria used in each case. Primary oocytes were represented by oogonias, which are the initial cells taking part in oogenesis, since they are differentiated in morphological features. Several researchers also consider oogonia as characterizing the first phase of oocyte development in Characiformes (Cecílio \& Agostinho, 1991; Marques et al., 2000; Garcia et al., 2001), while others (Bazzoli \& Rizzo, 1990; Ricardo et al., 1998) do not include these cells in oocyte development of some Characiformes, including Characidae. O. hepsetus showed oogonia isolated or in nests in all phases of oovarian development, but being more frequent in post-spawn period. Cecílio \& Agostinho (1991) related occurrence of oogonia during all reproductive cycles, in fish of different sizes. These authors suggest that oogonia originate oocytes that are cyclically eliminated.

Oocytes of $O$. hepsetus in early developmental phases present reduced cytoplasm, a large and central basophilic nucleus containing a nucleolus. In the initial and final perinucleolus phases, with the growth of the oocytes and a significant increase in their volume, there is a decrease in the relationship nucleuscytoplasm and an increased number of nucleoli followed by migration toward the nucleus periphery. This pattern was also observed in Astyanax fasciatus by Garcia et al. (2001). These researchers associated the number of nucleoli with increasing RNA synthesis that is essential to the oocyte development process, which in turn can be regarded as a complex celldifferentiation process involving the formation of numerous nucleoli, development of chromosomes and nuclear inclusion, and accumulation of different organelles, RNA, and citoplasmatic inclusions (Narahara, 1991).

Ovaries of $O$. hepsetus showed vesicles apparently empty in appearance, and containing endogen yolk, disperse in the cytoplasm, and lacking staining affinity. Overall, endogen yolk preceded exogen only in the late oocytedevelopment phases. During endogen vitelogenesis, the yolk vesicles are the first structures involved in the formation of the cortical alveoli to appear in the cytoplasm. According to Bazzoli \& Rizzo (1990), cortical alveoli play an important role in fertilization, since they are associated with the zona radiata in forming a barrier against fish polyspermy. During exogen vitelogenesis, a remarkable oocyte development occurs in $O$. hepsetus ovaries. In this phase the small yolk globules occupy a cortical oocyte position. They then become larger and occupy the entire cytoplasm, resulting in a notable oocyte volume increase. The nucleus shows an irregular contour with a high number of nucleoli, suggesting intense synthesis activity (Garcia et al., 2001). Increases in amount and volume of yolk globules, which occupy the whole cytoplasm, characterize mature oocytes with complete vitelogenesis, which in favorable conditions are spawned. Such oocytes showing these characteristics were observed for $O$. hepsetus at Lajes reservoir, and also for 
Oligosarcus argentus in fish culture ponds (Neves et al., 1995).

The appearance of zona radiata can occur in different oogenetic phases, according to the species (West, 1990). In O. hepsetus, this structure was detected early in the yolk vesicle phase, in which it appeared as thin and inconspicuous between the follicular cell layer and the oocytes. As $O$. hepsetus oocytes grow, the zona radiata increases in thickness and becomes more evident, as described by Bazzoli \& Godinho (1991) for Acestrorhynchus lacustris from the Três Marias reservoir, MG. According to Agostinho et al. (1987), this membrane: 1) controls the passage of substances to the interior of the oocytes during vitelogenesis; 2) protects the oocytes against physical injury; and 3) promotes, if necessary, adherence of the egg to the substrate following ovulation.
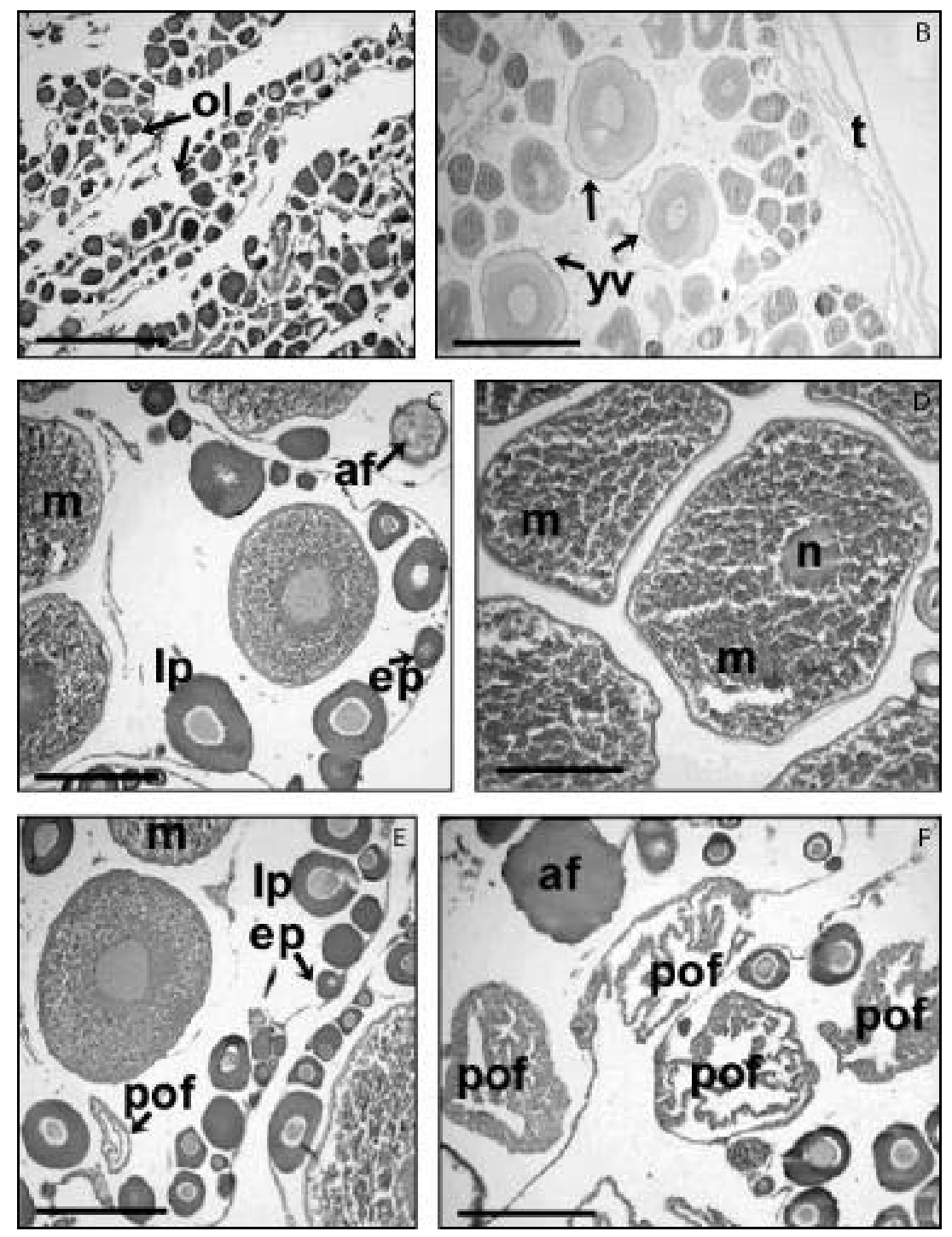

Fig. 2 - Histological sections of ovaries of Oligosarcus hepsetus showing ovarian development. (A) Ovary resting stage, ovuliferous lamellas (ol), scale bar $=100 \mu \mathrm{m}$. (B) Early maturing stage, yolk vesicle stage oocyte (yv), ovarian tunic $(\mathrm{t})$, scale bar $=100$ $\mu \mathrm{m}$. (C) Late maturing stage showing early perinucleolus stageoocytes (ep), late perinucleolus stage oocytes (lp), vitelogenic oocyte $(\mathrm{m})$ and atresic follicle (af), scale bar $=250 \mu \mathrm{m}$. (D) Mature ovary with vitelogenic oocytes (m), nucleus (n), scale bar $=250 \mu \mathrm{m}$. (E) Spawning stage ovary showing, early perinucleolus (ep) late perinucleolus (lp), vitelogenic oocytes (m) and postovulatory follicle (pof), scale bar $=250 \mu \mathrm{m}$. (F) Spawned ovary showing atresic follicle (af) and post-ovulatory follicles (pof), scale bar $=250 \mu \mathrm{m}$. 


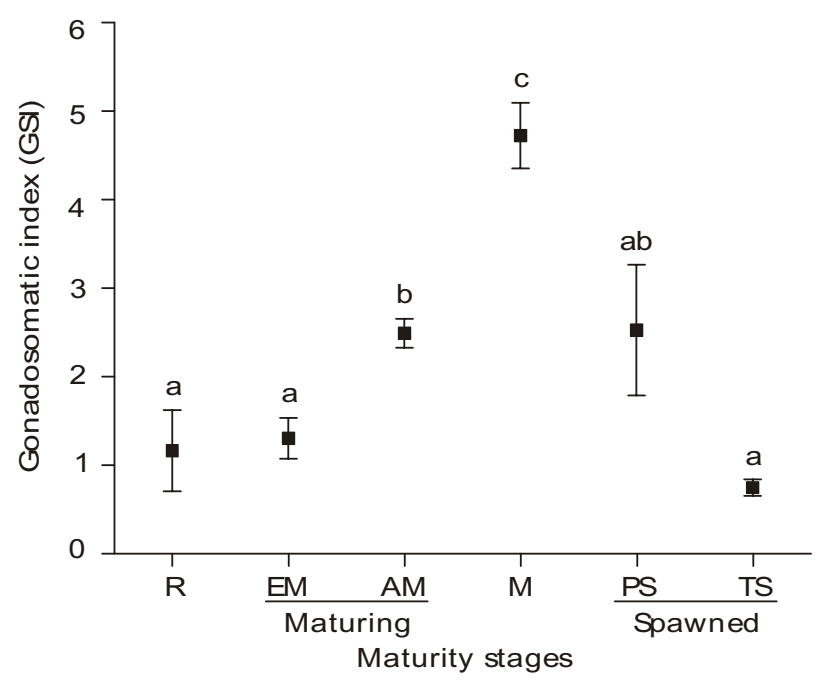

Fig. 3 - Gonadosomatic index (GSI) means and standard error (vertical lines) for each maturity stage of $O$. hepsetus in Lajes reservoir. $\mathrm{R}=$ resting; $\mathrm{EM}=$ early maturing; $\mathrm{AM}=$ advanced maturing; $\mathrm{M}=$ mature; $\mathrm{PS}=$ partially spawned; $\mathrm{TS}=$ totally spawned.

The degenerative phenomenon that occurs in the ovary (atresia) can happen in any phase of the reproductive cycle; in $O$. hepsetus, this was rare in oocytes in the initial phases, but more frequent in the late maturity phases or in oocytes not eliminated after spawning. The process of oocyte reabsorption can extend to maturation and spawns, in the presence of disturbances of biotic (food shortages and pathologies) and/or abiotic (changes in temperature and photoperiod) origin. According to Palmer (1995), atresia in advanced maturing and/or mature oocytes is associated to decreasing reproductive potential of a species.

When spawning occurs, the post-ovulatory follicle appears, originating the luteus body. After spawning, the post-ovulatory follicles begin a reabsorption and hormonal synthesis process (Vazzoler, 1996).

The number of gonadal stages and sub-stages can vary according to ovarian development for each species and also according to different criteria used by each author. Four stages and 4 sub-stages of ovarian development were recorded for $O$. hepsetus in the Lajes reservoir, through macro- and microscopic analysis. No immature stage was observed, probably due to reduced size of individuals caught $(>120 \mathrm{~mm}$ $\mathrm{TL}$ ), which included fish entering the reproductive cycle for the first time or re-starting this cycle. A similar number of stages and sub-stages with the immature stage also lacking, like that described for O. hepsetus, was also observed by Bazzoli \& Godinho
(1991), using histological techniques for the closely related Acestrorhynchus lacustris in Três Marias reservoir. Hartz et al. (1997) and Fialho et al. (1998) did not establish sub-stages for the gonadal development of Oligosarcus jenynsii in Rio Grande do Sul lakes. Hartz et al. (1997) recorded only 4 ovarian developmental phases, with no immature and resting stages found, while Fialho et al. (1998) described 5 stages, but did not finding the resting stage.

The GSI has been widely used as an indicator of the spawning period in fishes. However, its use in studies of reproductive biology is more suitable when associated to other indicators of reproduction, e.g., macroscopic and histological techniques. During the phases in which the gonads of $O$. hepsetus showed reduced volume (resting, initial maturation, and totally spawned), the GSI was about 1 . In the partially-spawned sub-stage, a wide GSI variation was shown. Such variation is probably due to the type of spawn, with gonads varying in the amount of vitelogenic oocytes during the early or late reproductive period. Gonads with a small amount of yolk oocytes, the majority in reabsorption, and a large amount of post-ovulatory follicles, characterize the totally spawned sub-stage. In the mature stage, the GSI reaches the highest values (about 5) due to the accentuated volume of gonads, which occupy almost the whole coelomic cavity.

Wide GSI variation in partially spawned substages, can be associated to occurrence of oocytes 
in different development stages and post-ovulatory follicles in the mature gonadal stage, evidencing spawn in batches of $O$. hepsetus in the Lajes reservoir. Based on observation of ovaries in several development stages, Bazzoli et al. (1996) reported that spawn in batches occurs in 4 Characidae species in Três Marias reservoir. Fishes that spawn in batches show the asynchrony type of ovarian development, with the oocyte development process occurring in stages, favoring successive spawns during the reproductive period. Spawn in batches occurs more frequently in species having stable environmental conditions, such as well-preserved or oligotrophic reservoirs (Mazzoni \& Iglesias-Rios, 2002). This reproductive strategy, which tends to decrease competition for sites and feeding resources for juveniles, seems to predominate in Characidae species. Some examples can be cited, i.e., Moenkhausia intermedia (Braga \& Gennari-Filho, 1990); Astyanax scabripinnis (Barbieri, 1992); Oligosarcus jenynsii (Hartz et al., 1997); and Bryconops cf. affinis (Nogueira et al., 1997). Batch spawning in $O$. hepsetus in Lajes reservoir can be classified as a reproductive tactic by which given environmental peculiarities are adapted to, thus favoring higher survival among juveniles.

Acknowledgements - This study was partially financed by Brazilian Agency for Research Development $(\mathrm{CNPq})$ and the Brazilian Ministry of Education's Coordination for Personal Training (CAPES). LIGHT Electricity S.A., concessionaire of the Lajes reservoir, supplied the infrastructure, essential to this project's development, as well as additional financial support. We specially thank Drs. Sebastião Paulino and Ricardo Bichara, as well as the technicians and undergraduate students of the Fish Ecology Laboratory, University Federal Rural of Rio de Janeiro, for helping in field and laboratory work. We are also indebted to the Histological Techniques Laboratory staff, and, in particular, Aparecida Alves Nascimento. We extend our gratitude to an anonymous referee for helpful comments on the manuscript.

\section{REFERENCES}

AGOstinhO, A. A., BARBIERI, M. C., BARBIERI, G. \& AGOSTINHO, C., 1987, Biologia reprodutiva de Rhinelepis aspera (Agassiz, 1829) (Teleostei, Loricaridae) no rio Paranapanema. II. Estrutura dos ovários e estádios de maturação. Rev. Bras. Biol., 47(3): 319-328.

AgOstinho, A. A., FerRetTI, C. L. M., GOMES, L. C., HAHN, N. S., SUZUKI, H. I., FUGI, R. \& ABUJANRA, F., 1997, Ictiofauna de dois reservatórios do rio Iguaçú em diferentes fases de colonização: segredo e foz de areia. In: A. A. Agostinho \& L. C. Gomes (eds.), Reservatório de segredo - bases ecológicas para o manejo. EDUEM, Maringá, pp. 319-364.
ARAÚJO, F. G. \& SANTOS, L. N., 2001, Distribution of fish assemblages in Lajes reservoir, Rio de Janeiro, Brazil. Rev. Bras. Biol., 61(4): 563-576.

BARBIERI, G., 1992, Biologia de Astyanax scabripinnis paranae (Characiformes, Characidae) do ribeirão do Fazzari, São Carlos, Estado de São Paulo. II. Aspectos quantitativos da reprodução. Rev. Bras. Biol., 52(4): 589-596.

BARROSO, L. V., 1989, Diagnóstico ambiental para a pesca de águas interiores no Estado do Rio de Janeiro. Rio de Janeiro. IBAMA-doc. ACUMEP (4): 117.

BAZZOLI, N. \& RIZZO, E., 1990, A comparative citological and cytochemical study of the ooenesis in ten Brazilian teleost fish species. Eu. Arch. Biol., 101: 399-410.

BAZZOLI, N., RIZZO, E., SANTOS, J. E. \& SATO, Y., 1996, Biologia reprodutiva de quatro espécies de peixes forrageiros da represa de Três Marias. Rev. Bios, M.G., 5(5): 17-28.

BAZZOLI, N. \& GODINHO, H. P., 1991, Reproductive biology of Acestrorhyncus lacustris (Reinhardt, 1874) (Pisces: Characidae) from Três Marias reservoir, Brazil. Zoo. Anz., 5/6: 285-297.

BRAGA, F. M. S. \& GENNARI-FILHO, O., 1990, Contribuição para o conhecimento da reprodução de Moenkhausea intermedia (Characidae, Tetragonopterinae) na represa de Barra Bonita, rio Piracicaba, SP. Naturalista, 15: 171-188.

CECÍliO, E. B. \& AGOSTINHO, A. A., 1991, Biologia reprodutiva de Hypophthalmus edentatus (SPIX, 1829) (Ostheichthyes, Siruliformes) no reservatório de Itaipú-PR. II. Estrutura dos ovários e escala de maturidade. Rev. UNIMAR., 13(2): 211-227.

CHAVES, P. T. C., 1991, Testículos: estrutura e dinâmica de maturação. pp. 47-50. In: Histologia de peixes. FUNEP, Jaboticabal, 77p.

FEEMA (Fundação Estadual de Engenharia do Meio Ambiente), 1988, Reservatórios e lagos do Estado do Rio de Janeiro. Relatório técnico da Fundação Estadual para Estudos do Meio Ambiente - FEEMA. Divisão de Qualidade de Água Departamento de Planejamento Ambiental, p. 180.

FIALHO, B. C., SCHIFINO, L. C. \& VERANO, J. R., 1998, Biologia reprodutiva de Oligosarcus jenynsii (GUNTHER) (Characiformes, Characidae) da Lagoa das Custódias, Tramandaí, Rio Grande do Sul, Brasil. Rev. Bras. Zool., 15(3): 775-782.

GARCIA, E. L., CHINI, H. A. S., MAISTRO, J. A. D. \& QUAGIOGRASSIOTTO, I., 2001, Dynamics and cytochemistry of oogenesis in Astyanax fasciatus (CUVIER) (Teleostei, Characiformes, Characidae) from Rio Sapucaí, Minas Gerais State, Brazil. Rev. Bras. Zool., 18(4): 1057-1064.

GOMES, I. D., ARAÚJO, F. G., AZEVEDO, M. C. C. \& PESSANHA, A. L. M., 2001, Escala de maturidade e época de reprodução de três bagres marinhos (Siruliformes: ariidae) na Baía de Sepetiba, RJ, Brasil. Comum. Mus. Ciênc. Tecnol. PUCRS, Sér. Zool., 14(1): 3-21.

HARTZ, S. M., VILELLA, F. S. \& BARBIERI, G., 1997, Reproduction dynamics of Oligosarcus jenynsii (Characiformes, Characidae) in lake Caconde, Rio Grande do Sul, Brazil. Rev. Brasil. Biol., 57(2): 295-203. 
HOAR, W. S., 1969, Reproduction. In: W. S. Hoar \& D. J. Randall. Fish physiology. Academic Press, London, 3: 1-72.

MAZZONI, R. \& IGLESIAS-RIOS, R., 2002, Environmentally related life history variations in Geophagus brasiliensis. $J$. Fish Biol., 61(6): 1606-1618.

MARQUES, D. K. S., ROSA, I. L. \& GURGEL, H. C. B., 2000, Descrição histológica de gônadas de traíra Hoplias malabaricus (Bloch) (Osteichthyes, Erythrinidae) da barragem do rio Gramame, Alhandra, Paraíba, Brasil. Rev. Bras. Zool., 17(3): 573-582.

NARAHARA, M. Y., 1991, Histofisiologia do ovário de teleósteos. pp. 39-46. In: M. Y. Narahara (eds.), Histologia de peixes. FUNEP, Jaboticabal, 77p.

NEVES, C. A., ANDRADE, D. R., MATTA, S. L. P., VIDAL, M. V. \& SANTOS, A. A., 1995, Cytochemical analysis of polysaccharides from the cortical alveoli of the oocytes of the lambari-bocarra (Oligosarcus argentus, Guinter, 1864) (Pisces, Characidae). Rev. Brasil. Biol., 55: 693-696.

NOGUEIRA, B. P., BAZZOLI, N., SANTOS, J. E. \& BARROS, M. D. M., 1997, Biologia reprodutiva do Bryconops cf. affinis $=$ Creatochanes affinis (Gunther, 1864) (Teleostei: Characiformes) na lagoa do Pantaninho, Lagoa da Prata, Minas Gerais. Rev. Bios, 5(5): 43-51.
PALMER, E. E., SORENSEN, P. W. \& ADELMAN, I. R., 1995, A histological study of seasonal ovarian development in freshwater drum in the Red Lakes, Minnesota. J. Fish Biol., 47: 199-210.

RICARDO, M. C. P., RIZZO, E., SATO, Y. \& BAZZOLI, N., 1998, Análise histológica da reprodução de Tetragonopterus chalceus Agassiz, 1829 (Pisces: Characidae) na represa de Três Marias, Minas Gerais. Rev. Bios, 6(6): 113-120.

RIZZO, E. \& BAZZOLI, N., 1993, Oogenesis, oocyte surface and micropylar apparatus of Prochilodus affinis Reinhardt, 1874 (Pisces, Characiformes). Eu. Arch. Biol., 104: 1-6.

SARRE, G. A., HYNDES, G. A. \& POTTER, I. C., 1997, Habitat, reproductive biology and size composition of Parequula melbournensis, a gerreid with a temperate distribution. $J$. Fish Biol., 50: 341-457.

VAZZOLER, A. E. A. M., 1996, Biologia da reprodução de peixes teleósteos: teoria e prática. EDUEM, Maringá, 169p.

WEST, G., 1990, Methods of assessing ovarian development in fishes: a review. Aust. J. Mar. Fresh. Res., 41: 199-222. 